DOI: $10.21554 / \mathrm{hrr} .091808$

\title{
THE IMPACT OF STUTTERING ON THE ABILITY TO ACQUIRE ACADEMIC KNOWLEDGE IN CHILDREN OF SCHOOL AGE
}

\author{
Nada Dobrota-Davidović ${ }^{1}$ \\ Jadranka Otašević \\ Ljiljana Radević
}

\author{
Original scientific paper
}

University of Belgrade, Faculty of Special Education and Rehabilitation, Republic of Serbia Institute of Psychophysiological Disorders and Speech Pathology "Prof. Dr. Cvetko Brajović",Belgrade, Republic of Serbia

\begin{abstract}
The aim of this research was to establish the level of abilities that is a prerequisite for acquiring academic knowledge of children who stutter. The sample consisted of 102 subjects, of whom 42 children were experimental, and 60 children constituted a control group. We used following instruments: Riley test - a test for stuttering estimation, for quantitative speech analysis and ACADIA - a capacity assessment test that is a prerequisite for the acquisition of academic knowledge. The obtained results showed that there are differences in perceptual, visuo-motor, non-verbal and speech-language abilities of children stuttering in relation to children who do not stutter. There is a significant connection between the stuttering and the success of the Serbian language and the stutter and education of the parents. These differences should be used as the starting point in a therapeutic program for working with children who stutter.
\end{abstract}

Key words: stuttering, academic knowledge, children of school age

\section{INTRODUCTION}

The speech is aware intentional dynamism of the continuous harmonic and rhythmic wave of sounds of various frequencies and intensity that maintains the psychophysical unity of the human being during the adaptation (Brajović, 1981). Observing such a wide process of listening and speaking, we can con- clude that the speech function, as well as the listening function, is extremely complex (Dobrota, 2011). Listening is the auditory process of higher nervous activity and conditioned by the maturation and experience factor.Outbursts in the early developmental period of the child can impair all levels of speechlanguage development and so that in the field of fluency of speech.

\footnotetext{
${ }^{1}$ Correspondence to:

Nada Dobrota - Davidović, University of Belgrade, Faculty of Special Education and Rehabilitation, Republic of Serbia

Visokog Stevana 2, Belgrade, Republic of Serbia

Phone: +38163280267

E-mail: nadadd@sbb.rs
} 
Stuttering is the most common fluency disorder and is defined as disfluency in speech. Disfluency can also occur in other pathological conditions - Tourette's syndrome, spastic dysphonia, Parkinsonism, palilalia, apraxia, tachifemia...

This is a non-fluent voice behavior that results from the existence of differences between: psycholinguistic factors (phonology, prose, syntax, semantics, cognition, pragmatics), psychosocial factors (parents and others that significantly influence the development and upbringing of children, fear, social burden of discourse) and physiological factors (beginning of voice and limited time, laryngeal and sublingeal tension, sensomotor coordination, articulation, anatomy of the nervous system, respiration and genetics) (De Nil, 1999).

Stuttering affects the entire personality of the child and should be viewed as a multidimensional problem, ie it should be observed through motor, linguistic, cognitive and emotional development and should be treated as such (Adams, 1990; Smith et al., 1996).

Basic academic skills include reading, writing and mathematical skills and their acquisition depends on personal and environmental factors. Personal factors are cognitive abilities and non-cognitive factors (child motivation, personality characteristics) that enable acquiring knowledge and skills (Gligorović 2013). The enviromental factors include: school, family and sociocultural milestones in which the child lives. The influence of enviromental factors is reflected on the quality of perceptual and motor functions that are an important link between emotional and cognitive development for the acquisition of academic knowledge and skills (Gligorović et al., 2011).

Intelligence is an important prerequisite for outcomes of education (Rhode \& Thompson, 2007) because there is a high correlation between intelligence and academic achievement (Nikolasević et al., 2014). Other research has confirmed the importance of specific cognitive functions and enviromental factors (Gligorović \& Buha 2010, 2012; Spinath et al 2006).

The aim of the research was to determine the level of abilities that are the prerequisite for acquiring knowledge in stuttering children and compare them with the abilities of children who do not stutter.

The specific objectives were:

1. Assess perceptual abilities in children who
stutTt2. Assess the perceptual abilities of nonstuttered children;

3. Assess viso-motor abilities in children of who stutter;

4. Assess visually-motor skills in non-stuttered children;

\section{METHODS}

In this paper the methods of research used are described in detail. The sample consisted of an experimental and control group. The experimental group consisted of 42 patients (33 boys and 9 girls) of the Institute for Psychophysiological Disorders and Speech Pathology "Prof. Dr CvetkoBrajovic "in Belgrade. During 2010/2011, they were treated for speech disorder by type of stutter, while the control group consisted of 60 students ( 40 boys and 20 girls) of elementary school age who did not stutter. The criteria for inclusion in the experimental group were: age (from 7 to 13 years), duration of speech therapy (6-12 months), level of intelligence (average and above average), weight of stuttering (light, medium and heavy), success at school, grade in Serbian language, grade in mathematics and education of parents.

Groups were harmonized with each other according to gender, age, school success, intelligence, success in mathematics and the Serbian language, and the education of father and mother.

In this research, the following instruments were used:

1. Riley test - This test evaluates quantitative speech analysis by following three parameters: frequency, physical concomitants, and duration of the longest block. The use of this test defines the degree of stinging difficulty (light, medium, heavy).

2. AKADIA - The test allows for registration of chilren that could have difficulty in mastering school materials due to some abilities that have not yet developed sufficiently. It is a test of developmental capabilities and consists of 13 subtests and each subtest evaluates cognitive functions. It is intended for children aged from 6.3 to 12.3 years. In the framework of data processing and analysis, adequate statistical methods have been applied which examined the significance of the variables tested: the measures of central tendency, variation measures, variance analysis, $\mathrm{t}$ - test, $\mathrm{Hi}$ - square test and graphical and tabular presentation. 


\section{RESULTS}

Table 1. Connection between intelligence and stuttering

\begin{tabular}{|c|c|c|c|c|c|}
\hline & & & \multicolumn{2}{|c|}{ Stuttering } & \multirow[b]{2}{*}{ TOTAL } \\
\hline & & & YES & NO & \\
\hline \multirow{4}{*}{ Intelligence } & & total & 26 & 46 & 72 \\
\hline & average & $\%$ & $61.9 \%$ & $76.7 \%$ & $70.6 \%$ \\
\hline & \multirow[b]{2}{*}{ extraordinary } & total & 16 & 14 & 30 \\
\hline & & $\%$ & $38.1 \%$ & $23.3 \%$ & $29.4 \%$ \\
\hline \multirow{2}{*}{\multicolumn{2}{|c|}{ Total }} & Total & 42 & 60 & 102 \\
\hline & & $\%$ & $100.0 \%$ & $100.0 \%$ & $100.0 \%$ \\
\hline
\end{tabular}

The $\chi^{2}$ test of independence showed no significant those who do not stutter, $23.3 \%$. Perhaps the differrelationship between stuttering and intelligence, $\chi 2$ ence is significant, but due to the smaller sample of $(1, \mathrm{n}=102)=1.931, \mathrm{p}=.165>.05$. Amongst those the respondents, this difference is not large enough to who stutter, $38.1 \%$ are super-intelligent, and among determine that it was due to the presence of stuttering.

Table 2. Results of testing effects of stuttering and intelligence on AKADIA test

\begin{tabular}{lccc}
\hline \multirow{2}{*}{ AKADIA test/subtests } & \multicolumn{3}{c}{ factor } \\
\cline { 2 - 4 } & stuttering & intelligence & stuttering*intelligence \\
\hline Auditory discrimination (1) & $\mathbf{. 0 0 2}$ & .297 & .684 \\
Visomotor discrimination and the possibility of herding (2) & $\mathbf{. 0 0 0}$ & $\mathbf{. 0 0 1}$ & .459 \\
Visual discrimination (3) & .541 & $\mathbf{. 0 0 1}$ & .419 \\
Drawing shapes (4) & $\mathbf{. 0 0 1}$ & .098 & .954 \\
Visual memory (5) & $\mathbf{. 0 0 2}$ & .221 & .091 \\
Audio-visual association (6) & .753 & $\mathbf{. 0 0 1}$ & .181 \\
Trace and encryption (7) & .305 & $\mathbf{. 0 0 0}$ & .727 \\
Auditory memory (8) & .213 & $\mathbf{. 0 0 3}$ & .171 \\
The skill of creating concepts (9) & $\mathbf{. 0 0 7}$ & $\mathbf{. 0 0 0}$ & .200 \\
Acquired language goods (10) & .945 & $\mathbf{. 0 0 6}$ & .770 \\
Automatic language goods (11) & $\mathbf{. 0 2 4}$ & $\mathbf{. 0 0 0}$ & .232 \\
Visual association (12) & .575 & $\mathbf{. 0 0 0}$ & .905 \\
Drawing (13) & .064 & $\mathbf{. 0 3 2}$ & .433 \\
\hline
\end{tabular}

This table shows the slight influence of stuttering on the coordination and traceability, Visual discrimination, subtests Auditory discrimination, Visuomotor coordi- Audio-visual association, Tracking and Encryption, nation and the possibility of herding, Drawing shapes, Auditory Memory, Creation Skills, Acquired Language Visual memory, Skill of creation of concepts and Au- Goods, Automated Lingual Treasures, Visual Associatomatic linguistic goods while on subtests Visuomotor tion, Drawing there is an influence of Intelligence. 
Table 3. Connection between success in Serbian language and stuttering

\begin{tabular}{|c|c|c|c|c|c|}
\hline & & & \multicolumn{2}{|c|}{ Stuttering } & \multirow[b]{2}{*}{ TOTAL } \\
\hline & & & YES & NO & \\
\hline \multirow{4}{*}{ Serbian } & & total & 12 & 6 & 18 \\
\hline & 4 & $\%$ & $29.3 \%$ & $10.2 \%$ & $18.0 \%$ \\
\hline & \multirow{2}{*}{5} & total & 29 & 53 & 82 \\
\hline & & $\%$ & $70.7 \%$ & $89.8 \%$ & $82.0 \%$ \\
\hline \multirow{2}{*}{\multicolumn{2}{|c|}{ Total }} & Total & 41 & 59 & 100 \\
\hline & & $\%$ & $100.0 \%$ & $100.0 \%$ & $100.0 \%$ \\
\hline
\end{tabular}

The $\chi 2$ test of independence showed a significant link between stuttering and success in Serbian language, the Serbian language in relation to stuttering students. $\chi^{2}(1, \mathrm{n}=100)=4.754, \mathrm{p}=.029$. A large number of

Table 4. Medium values on subtests for all combinations of success in Serbian language and stuttering

\begin{tabular}{|c|c|c|c|c|c|c|c|c|c|}
\hline \multirow{2}{*}{$\begin{array}{c}\text { AKADIA } \\
\text { test/subtests }\end{array}$} & \multirow{2}{*}{ grade } & \multicolumn{2}{|c|}{ stuttering } & \multirow{2}{*}{$\mathbf{p}$} & & \multirow{2}{*}{ grade } & \multicolumn{2}{|c|}{ stuttering } & \multirow{2}{*}{$\mathbf{p}$} \\
\hline & & yes & no & & & & yes & no & \\
\hline \multirow{2}{*}{$\begin{array}{l}\text { Auditory } \\
\text { discrimination (1) }\end{array}$} & 4 & $59.58 \mathrm{Ba}$ & $57.00 \mathrm{Aa}$ & \multirow{2}{*}{.003} & \multirow{2}{*}{ Auditory memory (8) } & 4 & $43.83 \mathrm{Aa}$ & $43.33 \mathrm{Aa}$ & \multirow{2}{*}{.721} \\
\hline & 5 & $59.45 \mathrm{Ba}$ & $58.04 \mathrm{Aa}$ & & & 5 & 44.90Aa & $47.72 \mathrm{Aa}$ & \\
\hline \multirow{2}{*}{$\begin{array}{l}\text { Visomotor } \\
\text { coordination and } \\
\text { possibility of herding } \\
\text { (2) }\end{array}$} & 4 & $45.08 \mathrm{Aa}$ & $50.33 \mathrm{Ba}$ & \multirow[b]{2}{*}{.007} & \multirow[b]{2}{*}{$\begin{array}{l}\text { The skill of creation } \\
\text { concepts }(9)\end{array}$} & 4 & $54.83 \mathrm{Aa}$ & $58.00 \mathrm{Aa}$ & \multirow[b]{2}{*}{.195} \\
\hline & 5 & $48.93 \mathrm{Ab}$ & $54.62 \mathrm{Bb}$ & & & 5 & 57.38Aa & $58.74 \mathrm{Aa}$ & \\
\hline \multirow{2}{*}{$\begin{array}{l}\text { Visual discrimination } \\
\text { (3) }\end{array}$} & 4 & $51.58 \mathrm{Aa}$ & $51.33 \mathrm{Aa}$ & \multirow{2}{*}{.962} & \multirow{2}{*}{$\begin{array}{l}\text { Aquired language goods } \\
\text { (10) }\end{array}$} & 4 & $58.92 \mathrm{Aa}$ & $60.50 \mathrm{Aa}$ & \multirow{2}{*}{.888} \\
\hline & 5 & $54.48 \mathrm{Ab}$ & $54.60 \mathrm{Ab}$ & & & 5 & $61.31 \mathrm{Aa}$ & $60.13 \mathrm{Aa}$ & \\
\hline \multirow{2}{*}{ Drawing shapes (4) } & 4 & $56.92 \mathrm{Aa}$ & $60.17 \mathrm{Ba}$ & \multirow{2}{*}{.038} & \multirow{2}{*}{$\begin{array}{l}\text { Automatic language } \\
\text { goods (11) }\end{array}$} & 4 & $55.67 \mathrm{Aa}$ & $59.33 \mathrm{Aa}$ & \multirow{2}{*}{.141} \\
\hline & 5 & $57.69 \mathrm{Aa}$ & $62.34 \mathrm{Ba}$ & & & 5 & $59.00 \mathrm{Aa}$ & $60.57 \mathrm{Aa}$ & \\
\hline \multirow{2}{*}{ Visual memory (5) } & 4 & $47.58 \mathrm{Aa}$ & 44.00Aa & \multirow{2}{*}{.676} & \multirow{2}{*}{ Visual association (12) } & 4 & 54.17Aa & $53.50 \mathrm{Aa}$ & \multirow{2}{*}{.777} \\
\hline & 5 & $47.76 \mathrm{Aa}$ & $53.53 \mathrm{Aa}$ & & & 5 & $57.83 \mathrm{Aa}$ & 57.36Aa & \\
\hline \multirow{2}{*}{$\begin{array}{l}\text { Audio-visual } \\
\text { association (6) }\end{array}$} & 4 & $48.92 \mathrm{Ba}$ & $37.17 \mathrm{Aa}$ & \multirow{2}{*}{.001} & \multirow{2}{*}{ Drawing (13) } & 4 & 44.33Aa & $39.00 \mathrm{Aa}$ & \multirow{2}{*}{.066} \\
\hline & 5 & $52.97 \mathrm{Aa}$ & $51.34 \mathrm{Ab}$ & & & 5 & 49.86Aa & $40.92 \mathrm{Aa}$ & \\
\hline \multirow{2}{*}{$\begin{array}{l}\text { Trace and encryption } \\
\text { (7) }\end{array}$} & 4 & 58.08Aa & $57.00 \mathrm{Aa}$ & \multirow{2}{*}{.786} & & & & & \\
\hline & 5 & 58.38Aa & $58.57 \mathrm{Aa}$ & & & & & & \\
\hline
\end{tabular}

On the Subtest of Auditory Discrimination and AudioVisual Association better results are achieved by students who stutter, while on the subtests Visuomotor Coordination and the Potential of Tracing and Drawing Forms better results are achieved by the children who do not stutter. On the subtest, the Audio-Visual Association there is an interaction between stuttering

Table 5. Connection between father's education and stuttering

\begin{tabular}{|c|c|c|c|c|c|}
\hline & & \multicolumn{4}{|c|}{ Stuttering } \\
\hline & & & YES & No & TOTAL \\
\hline \multirow{4}{*}{$\begin{array}{l}\text { Father - level of } \\
\text { education }\end{array}$} & & total & 29 & 23 & 59 \\
\hline & medium & $\%$ & $69.0 \%$ & $38.3 \%$ & $51.0 \%$ \\
\hline & & total & 13 & 37 & 50 \\
\hline & high & $\%$ & $31.0 \%$ & $61.7 \%$ & $49.0 \%$ \\
\hline \multirow{2}{*}{\multicolumn{2}{|c|}{ Total }} & Total & 42 & 60 & 102 \\
\hline & & $\%$ & $100.0 \%$ & $100.0 \%$ & $100.0 \%$ \\
\hline
\end{tabular}

and success in Serbian language. If we called for a $p$ value $(p=.001)$, we can conclude that stuttering affects the subtest Audio-Visual Association Standard and this would apply to both groups of respondents (and with grade 4 and grade 5), while it does not affect the respondent with a score of 5 . 
The $\chi 2$ independence test showed a significant rela- $(1, \mathrm{n}=102)=8.138, \mathrm{p}=.004$. The majority of stuttertionship between stuttering and father education, $\chi^{2}$ ing children have parents with secondary education.

Table 6. Meduim results on subtests for all combinations of level of father's education and stuttering

\begin{tabular}{|c|c|c|c|c|c|c|c|c|c|}
\hline \multirow{2}{*}{$\begin{array}{c}\text { AKADIA } \\
\text { test/subtests }\end{array}$} & \multirow{2}{*}{$\begin{array}{c}\text { Level of } \\
\text { father's } \\
\text { education }\end{array}$} & \multicolumn{2}{|c|}{ stuttering } & \multirow{2}{*}{$\begin{array}{c}\mathbf{p} \\
\text { value }\end{array}$} & & \multirow{2}{*}{$\begin{array}{c}\text { Level of } \\
\text { father's } \\
\text { education }\end{array}$} & \multicolumn{2}{|c|}{ stuttering } & \multirow{2}{*}{$\begin{array}{c}\mathbf{p} \\
\text { value }\end{array}$} \\
\hline & & yes & no & & & & yes & no & \\
\hline $\begin{array}{l}\text { Auditory } \\
\text { discrimination } \\
\text { (1) }\end{array}$ & $\begin{array}{l}\text { srednji } \\
\text { visoki }\end{array}$ & $\begin{array}{l}59.00 \mathrm{Aa} \\
60.69 \mathrm{Bb}\end{array}$ & $\begin{array}{l}58.39 \mathrm{Aa} \\
57.57 \mathrm{Aa}\end{array}$ & .000 & $\begin{array}{l}\text { Auditory memory } \\
\text { (8) }\end{array}$ & $\begin{array}{l}\text { srednji } \\
\text { visoki }\end{array}$ & $\begin{array}{l}41.90 \mathrm{Aa} \\
48.85 \mathrm{Aa}\end{array}$ & $\begin{array}{l}45.61 \mathrm{Aa} \\
48.51 \mathrm{Aa}\end{array}$ & .500 \\
\hline $\begin{array}{l}\text { Visomotor } \\
\text { coordination and } \\
\text { possibility of } \\
\text { herding (2) }\end{array}$ & srednji & 46.69Aa & $52.09 \mathrm{Ba}$ & .000 & $\begin{array}{l}\text { The skill of creation } \\
\text { concepts (9) }\end{array}$ & srednji & $56.38 \mathrm{Aa}$ & $58.17 \mathrm{Aa}$ & .131 \\
\hline $\begin{array}{l}\text { Visual } \\
\text { discrimination } \\
\text { (3) }\end{array}$ & $\begin{array}{l}\text { srednji } \\
\text { visoki }\end{array}$ & $52.83 \mathrm{Aa}$ & 53.78Aa & .949 & $\begin{array}{l}\text { Aquired language } \\
\text { goods (10) }\end{array}$ & $\begin{array}{l}\text { srednji } \\
\text { visoki }\end{array}$ & $\begin{array}{l}60.66 \mathrm{Aa} \\
60.31 \mathrm{Aa}\end{array}$ & $\begin{array}{l}59.74 \mathrm{Aa} \\
60.38 \mathrm{Aa}\end{array}$ & .705 \\
\hline $\begin{array}{l}\text { Drawing shapes } \\
\text { (4) }\end{array}$ & $\begin{array}{l}\text { srednji } \\
\text { visoki }\end{array}$ & $\begin{array}{l}56,38 \mathrm{Aa} \\
59.92 \mathrm{Aa}\end{array}$ & $\begin{array}{l}63.78 \mathrm{Aa} \\
60.97 \mathrm{Aa}\end{array}$ & .003 & $\begin{array}{l}\text { Automatic language } \\
\text { goods (11) }\end{array}$ & $\begin{array}{l}\text { srednji } \\
\text { visoki }\end{array}$ & $\begin{array}{l}56.62 \mathrm{Aa} \\
60.31 \mathrm{Aa}\end{array}$ & $\begin{array}{l}\text { 60.39Aa } \\
60.51 \mathrm{Aa}\end{array}$ & .149 \\
\hline $\begin{array}{l}\text { Visual memory } \\
(5)\end{array}$ & $\begin{array}{l}\text { srednji } \\
\text { visoki }\end{array}$ & $\begin{array}{l}46.62 \mathrm{Aa} \\
50.23 \mathrm{Aa}\end{array}$ & $\begin{array}{l}55.48 \mathrm{Ba} \\
50.92 \mathrm{Aa}\end{array}$ & .020 & $\begin{array}{l}\text { Visual association } \\
\text { (12) }\end{array}$ & $\begin{array}{l}\text { srednji } \\
\text { visoki }\end{array}$ & $\begin{array}{l}54.93 \mathrm{Aa} \\
60.62 \mathrm{Bb}\end{array}$ & $\begin{array}{l}57.65 \mathrm{Aa} \\
56.27 \mathrm{Aa}\end{array}$ & .597 \\
\hline $\begin{array}{l}\text { Audio-visual } \\
\text { association (6) }\end{array}$ & $\begin{array}{l}\text { srednji } \\
\text { visoki }\end{array}$ & $\begin{array}{l}50.72 \mathrm{Aa} \\
54.38 \mathrm{Aa}\end{array}$ & $\begin{array}{l}48.65 \mathrm{Aa} \\
50.35 \mathrm{Aa}\end{array}$ & .069 & Drawing (13) & $\begin{array}{l}\text { srednji } \\
\text { visoki }\end{array}$ & $\begin{array}{l}48.41 \mathrm{Ba} \\
47.92 \mathrm{Ba}\end{array}$ & $\begin{array}{r}39.48 \mathrm{Aa} \\
41,65\end{array}$ & .012 \\
\hline $\begin{array}{l}\text { Trace and } \\
\text { encryption (7) }\end{array}$ & $\begin{array}{l}\text { srednji } \\
\text { visoki }\end{array}$ & $\begin{array}{l}55.93 \mathrm{Aa} \\
61.15 \mathrm{Ab}\end{array}$ & $\begin{array}{l}57.26 \mathrm{Aa} \\
58.89 \mathrm{Ab}\end{array}$ & .739 & & & & & \\
\hline
\end{tabular}

From the table it can be seen that on the subtest Auditory Discrimination Stuttering statistically significantly increases the achievement values in children with highly educated fathers. On the Subtest Drawing, better results are achieved by children who stutter.
Non-stuttering children are more successful on the test Visuomotor coordination and possibility of herding. On subtests, Drawing Shapes and Visual memorystutter affects by reducing achievement value, and only in children whose fathers have secondary education.

Table 7. Connection between mother's education and stuttering

\begin{tabular}{|c|c|c|c|c|c|}
\hline & & & \multicolumn{2}{|c|}{ Stuttering } & \multirow[b]{2}{*}{ TOTAL } \\
\hline & & & YES & NO & \\
\hline \multirow{4}{*}{$\begin{array}{l}\text { Mother - level of } \\
\text { education }\end{array}$} & & total & 25 & 18 & 43 \\
\hline & medium & $\%$ & $59.5 \%$ & $30.0 \%$ & $42.2 \%$ \\
\hline & & total & 17 & 42 & 59 \\
\hline & high & $\%$ & $40.5 \%$ & $70.0 \%$ & $57.8 \%$ \\
\hline \multirow{2}{*}{\multicolumn{2}{|c|}{ Total }} & Total & 42 & 60 & 102 \\
\hline & & $\%$ & $100.0 \%$ & $100.0 \%$ & $100.0 \%$ \\
\hline
\end{tabular}

The $\chi 2$ independence test showed a significant relationship between stuttering and father education, $\chi 2$
$(1, \mathrm{n}=102)=7.662, \mathrm{p}=.006$. The majority of stuttering children have parents with secondary education. 
Table 8. Results of testing effects of stuttering and mother's education on AKADIA test

\begin{tabular}{|c|c|c|c|}
\hline \multirow[b]{2}{*}{ AKADIA test/subtests } & \multicolumn{3}{|c|}{ factor } \\
\hline & stuttering & mother's education & $\begin{array}{c}\text { stuttering*mother's } \\
\text { education }\end{array}$ \\
\hline Auditory discrimination (1) & .001 & .340 & .415 \\
\hline Visomotor discrimination and the possibility of herding (2) & .000 & .038 & .977 \\
\hline Visual discrimination (3) & .844 & .030 & .620 \\
\hline Drawing shapes (4) & .003 & .840 & .729 \\
\hline Visual memory (5) & .010 & .635 & .619 \\
\hline Audio-visual association (6) & .233 & .874 & .632 \\
\hline Trace and encryption (7) & .738 & .600 & .896 \\
\hline Auditory memory (8) & .257 & .452 & .784 \\
\hline The skill of creating concepts (9) & .284 & .088 & .431 \\
\hline Acquired language goods (10) & .333 & .249 & .023 \\
\hline Automatic language goods (11) & .080 & .556 & .765 \\
\hline Visual association (12) & .602 & .020 & .329 \\
\hline Drawing (13) & .003 & .160 & .565 \\
\hline
\end{tabular}

Table 8 - Results of testing effects of stuttering and mother's education on AKADIA test

From this table we can see the effect of stuttering the subtests of Visuomotor Coordination and the on the subtests Auditory discrimination, Visuomo- possibility of herding, Visual Discrimination and tor coordination and possibility of herding, Draw- the Visual Association. The interaction of these two ing shapes, Visual memory and Drawing. The ma- factors can be seen on the subtest Acquired linguisternal education factor has a significant impact on tic treasure.

Table 9. Average of achievement on AKADIA test for experimental and control group

\begin{tabular}{|c|c|c|c|c|c|}
\hline AKADIA test/subtests & Stuttering & $\mathbf{A S}$ & SD & $\mathbf{t}$ & p value \\
\hline \multirow[t]{2}{*}{ Auditory discrimination (1) } & yes & 59.520 & 2.051 & 3.410 & 0.001 \\
\hline & no & 57.880 & 2.598 & & \\
\hline \multirow[t]{2}{*}{ Visomotor coordination and possibility of herding(2) } & yes & 47.520 & 8.211 & -4.440 & 0.000 \\
\hline & no & 54.120 & 6.732 & & \\
\hline \multirow[t]{2}{*}{ Visual discrimination (3) } & yes & 53.570 & 5.939 & -0.410 & 0.681 \\
\hline & no & 54.000 & 4.540 & & \\
\hline \multirow[t]{2}{*}{ Drawing shapes (4) } & yes & 57.480 & 8.164 & -3.390 & 0.001 \\
\hline & no & 62.050 & 5.485 & & \\
\hline \multirow[t]{2}{*}{ Visual memory (5) } & yes & 47.740 & 9.284 & -2.560 & 0.012 \\
\hline & no & 52.670 & 9.771 & & \\
\hline \multirow[t]{2}{*}{ Audio-visual association (6) } & yes & 51.860 & 6.167 & 1.370 & 0.173 \\
\hline & no & 49.700 & 8.778 & & \\
\hline \multirow[t]{2}{*}{ Trace and encryption (7) } & yes & 57.550 & 7.510 & -0.530 & 0.594 \\
\hline & no & 58.270 & 6.056 & & \\
\hline \multirow[t]{2}{*}{ Auditory memory (8) } & yes & 44.050 & 13.870 & -1.410 & 0.162 \\
\hline & no & 47.400 & 10.150 & & \\
\hline \multirow[t]{2}{*}{ The skill of creation concepts (9) } & yes & 56.450 & 5.288 & -1.730 & 0.086 \\
\hline & no & 58.630 & 6.847 & & \\
\hline \multirow[t]{2}{*}{ Aquired language goods (10) } & yes & 60.550 & 6.209 & 0.400 & 0.691 \\
\hline & no & 60.130 & 4.304 & & \\
\hline \multirow[t]{2}{*}{ Automatic language goods (11) } & yes & 57.760 & 8.153 & -2080 & 0.040 \\
\hline & no & 60.470 & 4.928 & & \\
\hline \multirow[t]{2}{*}{ Visual association (12) } & yes & 56.690 & 7.788 & -0.070 & 0.941 \\
\hline & no & 56.800 & 6.976 & & \\
\hline \multirow[t]{2}{*}{ Drawing (13) } & yes & 48.260 & 11.565 & 2.690 & 0.008 \\
\hline & no & 40.820 & 15.102 & & \\
\hline
\end{tabular}


This table shows the mean values for all 13 subtests for stuttering. Using the $t$ test of independent samples, it is examined whether these differences are significant. In the tests Auditory discrimination, Visuomotor coordination and the possibility of herding, Drawing forms, Visual memory, Automatic linguistic goods and Drawing, there is a statistically significant difference in mean values that was created due to the influence of stuttering. For example, in the subtype Auditory discrimination, the difference is significant $(\mathrm{p}=.001)$, and as the average for the group who stutter (59.52) is higher than for a group that does not stutter (57.88), this means that the presence of stutter increases the values on this subtest, as well as on the subtest Drawing, while on the tests the Visuomotor Coordination and possibility of herding, Drawing Forms, Visual Memory, and Automatic Language goodspresence of stuttering reduces mean values.

For other variables, statistically significant association was not established.

\section{DISCUSSION}

By analyzing the results of the study of the connection of intelligence and stuttering, we have come to the conclusion that there is no statistically significant link between stuttering and intelligence, $p=.165>$ .05 . According to all parameters of descriptive statistics, students with superior intelligence achieve better results on all 13 subtests. This influence is statistically significant on subtests: Visuomotor coordination and possibility of herding, Visual discrimination, Audio-visual association, Trace and encryption, Auditory memory, Creation of concepts, Acquired linguistic goods, Automatic linguistic goods, Visual association and Drawing. On the subtype of Auditory discrimination, better results are achieved by the children who stutter.

$\chi^{2}$ test of independence showed a significant connection between stuttering and success in Serbian language $\chi^{2}(1, \mathrm{n}=100)=4.754, \mathrm{p}=.029$. A large number of children who do not stutter achieve great success in Serbian language in relation to stuttering students. This difference is statistically significant. According to the results of the AKADIA test, it can be concluded that on the subtests Auditory Discrimination and Audio-Visual Association better results are achieved by the children who stutter, while on the subtests The visuomotor coordination and the possibility of herding and Drawing shapes are better those who do not stutter.

The results of the $\chi 2$ independence test showed a sig- nificant relationship between the level of education of the father and stutter $(p=.004)$. More children are stuttering from the fathers with secondary education. Interpretation of achievements on the AKADIA test shows that on the subtests Auditory Discrimination and Drawing stuttering statistically significantly increases the achievement values of children with highly educated fathers. Non-stuttering children are more successful on subtests Vizuo-motor coordination and possibility of herding, Drawing Forms and Visual Memory. Stuttering reduces achievement values only in fathers with secondary education.

There was a conclusion that there is a significant link between level of education of mothers and stuttering $(\mathrm{p}=.006)$, where more children stutter in the group with secondary educated mothers. On subtests Auditory discrimination and Drawing better results are achieved by children who stutter, without significant influence of mother's education. On subtests, Visuomotor coordination and possibility of tracing, Drawing Shapes and Visual Memory better achievement have children who do not stutter. On the subtest, Visuomotor coordination and possibility of herding there is a statistically significant influence on mother's education, since those with highly educated mothers are more successful in both categories of children.

Observed through the achievements of the control and experimental group on the AKADIA test, the following conclusions are: that by using the $t$ test of independent samples on the test Auditory Discrimination there is a statistically significant difference in median values that resulted byimpact of stuttering $(p=.001)$. Average for group who stutter (59.52) is higher than for a non-stuttering group (57.88). This means that the presence of stutter increases the values on this subtest as well as on the subtest Drawing $(\mathrm{p}=.008)$. On the subtests, Visuomotor Coordination and possibility of herding, Drawing Forms, Visual Memory and Automatic Language goods, presence of stuttering reduces medium values (better results have non-stuttering children).

\section{CONCLUSION}

Based on the results of the research that pointed out the deviations and differences in the developmental abilities of children stuttering in relation to the children who are not stuttering, in the therapeutic work with this group of children, it is necessary to introduce a special approach and a procedure that takes into account their limitations and potentials. 
This work was concerned with the analysis of those skills that are necessary for school skills (reading, writing, mathematical skills, wider success and socialization).

According to some studies, the achievements on the AKADIA test are a statistically significant factor in the success in the Serbian language. Such data confirmed the significance of this test and the justification of its application in assessing the preparedness of children of the younger school age to acquire academic knowledge and skills. Some other studies have shown that success in language teaching depends on linguistic competence, which is conditioned by cognitive potential as well as the quality of auditory information processing / auditory attention, phonological awareness, auditive discrimination, short-term and long-term verbal memory.

Difficulties in stuttering children are present in perceptual, linguistic, non-verbal and viso-motor skills. They should be the initiation of the development of a preventive and stimulating program that is part of the therapeutic process.

\section{REFERENCES}

Adams, M.R. (1990). The demands and capacities model I: Theoretical elaborations. Journal of Fluency Disorders, 15, pp. 135-141.

Brajović C., Brajović Lj. (1981). Rehabilitacija poremećaja funkcije govora. Beograd: Naučna knjiga.

De Nil L.F. (1999). The multidimensional nature of stuttering. U: N.B. Ratner i E.C. Healey (Ed.) Stuttering research and practise (s.85-102). New Jersey, Lawrence Erlbaum Associates.
Dobrota N. (2011). Poremećaji fluentnosti. Beograd: Zavod za psihofiziološke poremećaje i govornu patologiju "Prof. dr Cvetko Brajović", Univerzitet u Beogradu, Fakultet za specijalnu edukaciju i rehabilitaciju.

Gligorović M. (2013). Klinička procena i tretman teškoća u mentalnom razvoju. Beograd: Univerzitet u Beogradu FASPER, CIDD.

Gligorović M., Buha N. (2013). Veština crtanja kod dece sa lakom intelektualnom ometenošću. VII Međunarodni skup "Specijalna edukacija i rehabilitacija", Beograd, 27-29 septembar, Zbornik radova, pp. 57-65

Gligorović M., \& Buha-Đurović N. (2010). Excesutive functions and achievements in art education in children with mild intellectual disability. Specijalna edukacija i rehabilitacija, 9(2), pp. 225-244

Gligorović M., Radić Šestić M., Nikolić S., Ilić Stošović D. (2011). Perceptual-motor abilities and prerequisies of academic skills. Specijalna edukacija i rehabilitacija, 10, 3, pp. $405-434$

Nikolašević Ž, Bugarski - Ignjatović V, Milovanović I, Raković S. (2014). Inteligencija i školsko postignuće u svetlu naslednih i sredinskih činilaca. Primenjena psihologija, 7(3), pp. 381-400

Rhode T.E., Thompson L.A. (2007). Predicting academic achievement with cognitive ability. Intelligence, 35(1), pp. 83-92. doi: 10.1016/j.intell.2006.05.0004

Smith A., Denny M., Shaffer L., Kelly E., Hirano M. (1996). Activity of intrisnic laryngeal muscles in fluent and disfluent speech. Journal of Speech, Hearing Researgh 39, 2, pp. 329-348

Spinath B., Spinath F.M., Harlaar N., Plomin R. (2006). Predicting school achievement from general cognitive ability, self-percieved ability and intrinsic value. Intelligence, 34, pp. 363-374. doi.org/10.1061/j.intell.2005.11.004. 